\title{
DIGITALIZACE ETIKET STANDARDNÍCH ŠELAKOVÝCH DESEK JAKO NÁSTROJ PRO EFEKTIVNÍ MUZEJNÍ EVIDENCI: VÝSLEDKY PRŮZKUMU VE SBÍRCE FONOTÉKY NÁRODNÍHO MUZEA - ČESKÉHO MUZEA HUDBY
}

\author{
DIGITIZATION OF PHONOGRAPH RECORDS LABELS AS A TOOL \\ FOR EFFECTIVE MUSEUM RECORD-KEEPING: \\ RESULTS OF A SURVEY OF THE COLLECTION OF THE NATIONAL \\ MusEuM - CZECH MusEum OF MusIC \\ Gabriel Gössel, Martin Mejzr, Michal Studničný, Filip Šír \\ Národní muzeum
}

\begin{abstract}
Abstrakt
Účel - Cílem předkládaného odborného článku je ozřejmit př́nosy zavedení procesu fotografického snímání etiket gramofonových desek v souvislosti s problematikou evidence sbírek fonotéky Národního muzea - Českého muzea hudby. Digitalizace etiket, $\mathrm{v}$ tomto př́padě standardních šelakových desek, je v textu nahližena jako nebývale účinný nástroj pro evidenční praxi muzejní práce. Zachycení digitálního obrazu etikety zároveň prrináší další výhody týkající se popisu, studia i hodnocení sbírek tohoto typu zvukových nosičů.

Design/metodologie/př́stup - Na základě průzkumu fyzického stavu sbírky zvukových nosičů a dochovaných evidenčních pomůcek bylo provedeno vlastní zavedení fotografického snímání etiket gramofonových desek. Následné zpracování elektronické evidence ve formě tabulky vytvořilo za pomoci dostupných nástrojů (řazení a filtrace) základ pro odborné zhodnocení sbírky a sestavení statistického přehledu.

Výsledky - Zamýšlenými výsledky průzkumu sbírky gramofonových desek jsou 1) evidenční tabulka sbírky s odborně-kriticky vybranými kategoriemi 2) na jejich základě vypracované statistiky, ve kterých jsou vyhodnoceny nejčastější výskyty (např. nejčastější druh poškození, nejčastější výskyt vydavatelských firem atd.). Stěžejním výsledkem je však samotné zavedení fotografické digitalizace etiket nosičů jako účinné pomůcky k jejich evidenci, bez které by výše jmenované výsledky ani nevznikly.

Originalita / hodnota - Př́nosem celého průzkumu je celá řada výhod digitální podoby evidence, která překonává tradiční zavedené metody v praxi pamět’ových institucí (zejména v knihovnách a muzeích), a to hned v několika rovinách: v dlouhodobé šetrnosti ke sbírkovým předmětům, v urychlení samotného evidenčního procesu, ve snadnější dostupnosti digitalizovaného obsahu a v potenciálu mnohem komplexnějšího hodnocení jak jednotlivých sbírkových předmětů, tak sbírky jako celku.

Klíčová slova: muzeum, digitalizace, evidence, katalogizace, gramofonová deska, zvukové dokumenty, šelaková deska, muzejní sbírka, etiketa gramofonové desky
\end{abstract}




\section{Abstract}

Purpose - The purpose of the research study is to explain the process of introducing photographic documentation of gramophone record labels in connection with the issues of record-keeping within the sound archive collections of the National Museum - Czech Museum of Music. The digitization of labels, in this case standard shellac discs, is seen in the text as an unprecedentedly effective tool in the record-keeping practices of the museum. At the same time, the use of the digital image of the label offers additional advantages in describing, studying and evaluating collections of this type of audio media.

Design / Methodology / Approach - Based on a survey of the physical state of sound carrier collections and surviving records, an innovative approach of photographic label scanning was implemented. Subsequent processing of electronic evidence into spreadsheet form was performed, using available tools (sorting and filtering), as a basis for expert assessment of the collection and for compiling a statistical overview.

Results - The intended results of a survey of record labels are 1) a table populated with professionally-curated, accurate data data 2) the compiled statistical data can be used to evaluate the most frequent occurrences of an attribute of the collection (eg. the most frequent type of damage found, the most prolific publishing companies, etc.). The key result, however, is that it introduces photographic digitisation (ergo, preservation) of labels as an effective aid to their evidence, without which the above-mentioned results would not have come to be.

Originality / Value - The benefits of the survey are the many advantages of having a digital representation of the object, one which overcomes the limitations of traditional, established methods in practice as part of memory institutions' processes (especially in libraries and museums). It offers improvements on several levels: in the process of long-term preservation of collection items, in making digitized content available more easily, and in the potential for providing a more comprehensive assessment of both individual collection items and collections as a whole.

Keywords: museum, digitization, evidence, cataloging, gramophone record, audio documents, shellac, museum collection, phonograph label 


\section{Úvod}

Gramofonová deska spatřila světlo světa na konci 19. století, v "cimrmanovské” době překotných vynálezů, kdy technický pokrok měnil okolní svět takřka každým dnem. Objev tohoto plochého, tenkého, okrouhlého kotouče proměnlivé velikosti, materiálu i rychlosti přehrávání, je spojen se jménem Emile Berlinera, německého židovského emigranta do USA, který nechal svou technologii patentovat $\mathrm{v}$ roce 1887. Gramofonová deska, jako jedno z nejstarších médií záznamu a reprodukce zvuku, se ve svých elementárních principech za svou stoletou historii př́liš nezměnila. Zvuková stopa je na gramofonové desce vyryta (resp. vylisována) ve formě spirálové drážky vedoucí na záznamovém poli směrem od vněǰ̌í hrany ke středu. Uprostřed gramofonové desky je kruhová plocha, kde se z důvodu zhoršující se kvality nahrávání směrem ke středu nosiče nenachází stopa zvukového záznamu.

Tento prázdný prostor se prakticky již od vynálezu gramofonové desky na konci 19. století stal místem, které bylo využito pro určení a označení charakteristických informací o daném nosiči a nahrávce (Miřátský, 1958). Nejdř́ve popsané kř́ídou či vyryto do povrchu, později v podobě etikety gramofonové desky, zpravidla natištěný či nadepsaný papírový kruh vlepený na povrch nosiče, jsou spolu s tzv. zrcátkem klíčovým zdrojem informací o obsahu, výrobě či původu zvukového záznamu a fyzického nosiče zároveň. Zrcátkem je nazýván prostor mezi etiketou a plochou gramofonové desky, kde je zaznamenaný zvuk. Označení získalo od lesku a zrcadlení obrazu z důvodu chybějící zvukové stopy. Z knihovnického pohledu je etiketa ekvivalentem titulního listu knihy, a slouží tak v pamětových institucích jako preferovaný (mnohdy jediný) pramen bibliografického popisu (Benešová, Štorová, 2015).

Předmětem prezentované studie je právě ústřední role a význam etikety gramofonové desky v souvislosti s úskalími a praktickými problémy evidence a katalogizace těchto zvukových nosičů v českých pamět’ových institucích. Př́spěvek čerpá z průběhu, výsledků a nabytých zkušeností v rámci průzkumu stavu sbírky zvukových nosičů fonotéky Národního muzea - Českého muzea hudby, který byl proveden na vzorku 10000 standardních šelakových desek o průměru $30 \mathrm{~cm}$. Administrativně je celý průzkum součástí výzkumné oblasti s názvem Problematika zvukových dokumentů v rámci financování dlouhodobých vědeckých projektů Věda a výzkum Národního muzea. Zmíněný průzkum byl jen jedním z několika dílićích cílů v rámci řešení této problematiky v Národním muzeu v roce 2018. Předkládaný text má za cíl ukázat proces digitálního zachycení etikety gramofonových desek jako východiska a efektivního nástroje na řešení mnohdy neutěšených problémů $\mathrm{v}$ praxi evidence sbírek zvukových nosičů. 


\section{Etiketa gramofonové desky a její informační hodnota}

Ačkoliv se grafická podoba a mnohdy bohaté estetické ztvárnění etiket lišily napřríč časem a prostorem, základní údaje zde uvedené obsahují obdobné kategorie. Obvykle etiketě vizuálně dominuje grafické logo, z drtivé většiny je to název firmy, společnosti, závodu či jiného vydavatele. Následují pak název skladby (či literárního díla), velmi často jsou zde také zaznamenáni autoři a interpreti (v př́padě hudebního obsahu libretisté, sólisté, dirigenti a dalšî), nebo interpretující hudební tělesa (Horová; Hrubá, 2018).

Etiketa také může obsahovat další specifické údaje (např. nástrojové obsazení, tóninové označení, označení tempa, aj.). Mnohdy je na etiketě např́iklad uvedena dobová cena nosiče. V neposlední řadě se u novějších typů gramofonových desek vyskytuje poznámka o autorských a vydavatelských právech. $\mathrm{Na}$ československých gramofonových deskách se např. můžeme setkat s textem, který upozorňuje, ẓ̌e všechna práva autori a výrobcu, rozblasovébo sǐrení a verégnébo provozování json vybrazena autorìm díla a výrobciom gramofonové desky. Na etiketě mohou být rovněž uvedeny i konkrétní zkratky institucí jako OSA (Ochranný svaz autorský pro práva $\mathrm{k}$ dílům hudebním) či BIEM (Bureau international de l'édition mécanique - Mezinárodní úřad pro mechanickou edici) (Šeda, 1957).

Zásadním údajem na etiketě je tzv. objednací číslo, které původně sloužilo zákazníkům k vyhledávání titulů v katalozích jednotlivých gramofonových firem a vydavatelství. Části objednacího čísla jako prefix a sufix mohou zároveň vypovídat o průměru nebo cenové, repertoárové či umělecké kategorii. Tyto dobové katalogy neocenitelně zachycují vydavatelskou činnost, protože obsahují vždy kompletní a ucelený seznam nabízených komerčně vydaných zvukových nosičů. Na etiketě lze nalézt matriční číslo, které je rovněž vylisované na zrcátku. Jedná se o unikátní identifikační či evidenční číslo, které je pro každou stranu desky jiné. Jedna deska má tak zpravidla dvě různá matriční čísla a slouží k evidenci výroby desek. Pokud by byl tento typ identifikátoru desky podroben rozboru, tak z něj lze vyčíst datum přesného nahrání zvukové stopy na desku, prefix a sufix pak zde slouží k určení nahrávacího technika. Dále se zde může nacházet symbol značící elektricky nahraný záznamu, či pořadí zvukového snímku (Gössel, Šír, 2016).

\section{Instituce, historie a její sbírky: Národní Muzeum - České muzeum hudby}

České muzeum hudby patři v rámci objemnosti a početnosti sbírek zvukových nosičů mezi nejdůležitější pamět'ové instituce v České republice. Oficiálně se stalo toto muzeum součástí Národního muzea až v roce 1976 a je tedy nejmladší ze současných pěti institucionálních pilîrư této největší a nejstarší české národní muzejní instituce. K původní trojici (Knihovna Národního muzea, Historické muzeum a Př́rodovědecké muzeum), která tvořila od roku 1818 základ sbírky Národního muzea, se v roce 1943 přidalo Náprstkovo muzeum a později právě muzeum zaměřené na předměty hudebního charakteru (Čížek, 1999).

Předměty hudebního charakteru se však začaly ve sbírkách Národního muzea objevovat prakticky od jeho založení. Speciální hudebně-historická sbírka vznikla až v roce 1913 a to díky hudebnímu skladateli a muzikologovi Emilu Axmanovi (*1887-†1949). Samostatné hudební oddělení vzniklo v roce 1946 a sídlilo ve Velkopřevorském paláci v Praze na Malé Straně. V roce 1976 pak spojením hudebního oddělení 
Národního muzea s dalšími dvěma institucemi (muzeum Antonína Dvořáka a muzeum Bedřicha Smetany) vzniklo Muzeum České hudby. S rokem 2001 došlo k přejmenování, pod nímž je známé dodnes - České muzeum hudby.

V roce 2004 došlo $\mathrm{k}$ přestěhování hlavní budovy muzea $\mathrm{z}$ Velkopřevorského paláce jen o několik blokủ a ulic dál, do budovy bývalého kostela sv. Mář́ Magdalény v Karmelitské ulici. Tato unikátní historická stavba, s jejîž rekonstrukcí pro muzejní účely se začalo jen o dva roky dř́ve, v roce 2002, změnila mnohokrát ve své historii funkci. Kromě své původní sakrální úlohy sloužila např. jako sklad cukrovaru, poštovní úřad, četnická kasárna a naposledy přešla do majetku Státního ústředního archivu. Pod správu Českého muzea hudby spadá kromě budovy v Karmelitské ulici na Malé Straně ještě dalš́ch 6 objektů, z nichž se shodně tři nachází v Praze (Muzeum Antonína Dvořáka, Muzeum Bedřicha Smetany a Památník Jaroslava Ježka (tzv. Modrý pokoj), a tři zbývající pak ve středních Čechách (Památník Antonína Dvořáka v Nelahozevsi, Památník Bedřicha Smetany v Jabkenicích, Památník Josefa Suka v Křečovicích.)

V současné době uchovává České muzeum hudby okolo 700000 sbírkových předmětů. Největší počty jednotek obsahují sbírky notového archivu a fonotéky, s rozsáhlou kolekcí zvukových nosičǔ. Sbírky spadají do gesce trrí samostatných odborů. Prvním je Oddělení hudebních nástrojů, jehož předměty jsou základem pro stálou expozici nazvanou Člověk - Nástroj - Hudba. Druhým je Hudebně historické oddělení (pod které administrativně spadají jak fonotéka, tak i notový archiv či další sbírkové úseky. Třetím je v roce 2008 nově založené Centrum pro dokumentaci populární hudby a nových médií. Dokumenty, materiály a předměty $z$ dalších sbírek, jež jsou svým původem, stárím, osudem i zaměřením spjaté s hudební historií českých zemí, jsou pro veřejnost dostupné $\mathrm{v}$ badatelně formou prezenčního studia. Kromě odborně tematické knihovny a zmíněných sbírek notového archivu, resp. fonotéky jsou to např. sbírky ikonografických předmětů (busty, obrazy, fotografie, řády aj.), specifické hudebniny (duchovní písně, liturgické chorální knihy, duchovní a světská polyfonní hudba), tzv. nenotové písemnosti (korespondence, osobní doklady interpretů či skladatelů), tisková dokumentace (sbírka programů, plakátů ke koncertům a divadelním představením, výstřǐ̌ky z novin aj.) nebo sbírka osobních pozůstalostí, např́iklad Zdeňka Fibicha, Vítězslava Nováka nebo Josefa Suka (celé viz Průvodce ČMH 1999).

\section{Fonotéka Národního muzea - Českého muzea hudby}

Hned v úvodu je důležité zmínit, že i přes svưj název nelze považovat fonotéku Národního muzea Českého muzea hudby za fonotéku v pravém slova smyslu. Slovem fonotéka se totiž ve významu, v jakém se používá především $\mathrm{v}$ anglosaském knihovnickém prostředí, označuje část či oddělení knihovny, které zajišt’uje prezenční výpůjčky pro zájemce v podobě poslechu zvukových nahrávek. Fonotéka je v př́ípadě Národního muzea spíše specifickým typem archivu, který zvukové nahrávky pouze uchovává, ale prozatím je nezpř́stupňuje. V rámci Českého muzea hudby funguje v praxi fonotéka jako jedna z částí Hudebně historického oddělení, která zprostředkovává prríslušné sbírkové předměty (v tomto př́padě zvukové dokumenty) především pro výstavní či badatelské účely. 
Zvukové dokumenty byly v rámci Českého muzea hudby zařazeny mezi kategorie sbírkových předmětů až od šedesátých let 20. století (Čížek, 1999). I přes to, že se jedná o historicky nejmladší sbírkový úsek instituce, sbírka fonotéky Národního muzea - Českého muzea hudby čítá v současné době téměř sto tisíc sbírkových předmětů. Sbírkový úsek se v Českém muzeu hudby rozlišuje podle povahy sbíraných předmětů. Vedle sbírkového úseku fonotéky jsou zde dále úseky se sbírkami tiskové dokumentace (plakáty a programy), notový archiv, ikonografie aj. $V$ případě sbírkového úseku fonotéky se jedná o zvukové nosiče nejrůznějších typů, velikostí, odlišného stáŕí i dochovaného stavu. Mezi nejstarší nosiče ve sbírce fonotéky patří napřr. fonografické válečky firmy “Edison”, tedy vyrobené společností založenou slavným americkým vynálezcem Thomasem Alvou Edisonem (Gössel, 2001). Sbírka fonografických válečků čitá celkem 1155 evidovaných nosičů, které pocházejí přibližně z let 1902-1915.

Sbírka fonotéky Národního muzea - Českého muzea hudby také obsahuje dnes velice populární vinylové desky, dále nosiče kompaktních disků CD, DVD, magnetofonových kazet a VHS kazet. Ve sbírce fonotéky jsou rovněž dnes už poněkud bizarní a raritní média doby nedávné jako např. r-dat kazety, ale také nosiče typu laser disc či minidisc. Rovněž se zde nachází sbírky tzv. fonopohlednic či fonofolií.

Nejpočetněji zastoupeny jsou však standardní gramofonové desky, které jsou pamětníkům, zainteresovaným znalcům a sběratelům známé spíše pod označením “šelakové desky”. Standardní desky vlastní fonotéka jak v jejich obvyklých rozměrech $(17,25$ a $30 \mathrm{~cm})$, tak i v atypických velikostech a materiálech. Za jádro fonotéky lze považovat ucelený komplex nosičů, který tvoři přibližně 50000 standardních gramofonových desek prakticky z veškerých období jejich výroby (od počátku dvacátého století až po poslední výlisy firmy Supraphon z první poloviny šedesátých let). Národní muzeum je získalo prostřednictvím tzv. převodů z tradičních institucí a společností jako byly (a jsou) Supraphon nebo Český rozhlas. Jen pro porovnání, jiný početně široký sbírkový komplex - sbírka vinylů - představuje přes 28000 nosičů, které se do muzejního majetku dostaly v tak velkém počtu $\mathrm{z}$ důvodu přebírání tzv. povinného výlisu. Ten byl v éře socialistického Československa zastoupen zejména nosiči již uvedeného Supraphonu (Čížek, 1999).

Co se týče charakteristiky a rysů evidenčního systému v rámci fonotéky Národního muzea - Českého muzea hudby, původně bylo pro všechny sbírkové předměty (především gramofonové desky různých rozměrů a z různých materiálů) zavedeno označení identifikační značkou $\mathrm{M}$, a to jako prefix před inventárním číslem. Evidenční číslo spadá v rámci muzeí do systematické evidence sbírkových předmětů. Inventární č́slo je identifikátorem sbírkového předmětu a slouží jako podklad pro inventarizaci sbírek (Jirásek, Kervitcerová, Žalman, 2002). Všechny druhy nosičů (především gramofonové desky různých rozměrů) bylo tehdy možné vyhledat pod tímto označením a jednou evidenční pomůckou - inventářem M. Samotné fyzické uložení sledovalo jednoduše číslování inventární řady. Později však byla provedena celková reorganizace fyzického uložení podle zcela jiného rozhodovacího klíče, a sice podle typu a velikosti nosičů. Tato systémová změna si pochopitelně vynutila i úpravu identifikačních značek, resp. písmových prefixů. Pro přehlednost a jednodušší orientaci príkládáme tabulku obsahující seznam nových značení včetně jednotlivých typů nosičů: 


\begin{tabular}{|l|l|}
\hline $\begin{array}{l}\text { značení inventárních řad } \\
\text { fonotéky Národního } \\
\text { muzea - Českého muzea } \\
\text { hudby k roku 2019 }\end{array}$ & typ zvukového nosiče - sbírkového předmětu \\
\hline MA & LP - long playing, vinylové desky o průměru $30 \mathrm{~cm}$ \\
\hline MB & EP - extended playing, vinylové desky o průměru $25 \mathrm{~cm}$ \\
\hline MC & SP - single play, vinylové desky o průměru $17 \mathrm{~cm}$ \\
\hline MCD & kompaktní disky \\
\hline MD & gramofonové desky atypických formátů a materiálů \\
\hline ME & gramofonové desky z šelaku o průměru $30 \mathrm{~cm}$ \\
\hline MF & gramofonové desky z šelaku o průměru $25 \mathrm{~cm}$ \\
\hline MG & fonopohlednice \\
\hline MH & fonografické válečky \\
\hline MID & minidisk \\
\hline MK & audiokazety \\
\hline MKU & U matic kazety \\
\hline ML & magnetofonové pásy \\
\hline MLD & laserový disk \\
\hline MR & gramofonové desky o průměru $40 \mathrm{~cm}$ \\
\hline MT & R-dat kazety \\
\hline MVC & kazety VHS \\
\hline MVD & kompaktní disky DVD \\
\hline
\end{tabular}

Tab. 1 Prébled značeni jednotlivých inventárních ràd ve fonotéce Céskébo muzea budby

\section{Průzkum standardních gramofonových desek o průměru $30 \mathrm{~cm}$}

S vědomím tak rozsáhlé reorganizace a přeskupování sbírky v minulých dobách bylo rozhodnuto, že bude proveden průzkum formou sondy do některé ze sbírek za účelem zjištění podrobností jejího fyzického stavu a evidence. Podle oficiálního znění dílčího cíle $\mathrm{v}$ rámci projektu Věda a výzkum Národního muzea by měl být vyhodnocen komplexní průzkum první části sbírky Českého muzea hudby se zaměřením na gramofonové desky o velikosti $30 \mathrm{~cm}$ o řadě 1 - 10000 kusů, který probíhal v letech 2018-2019. Pro průzkum byla konkrétně pak vybrána nejrozsáhlejší část celé sbírky fonotéky označená prefixem ME. Aktuální údaje čítaji pro inventární řadu ME celkem 28103 gramofonových desek, které jsou fyzicky uloženy celkem v 1405 krabicích, a umístěny v muzejním depozitáři Národního muzea - Českého muzea 
hudby. Spolu se sbírkou fonografických válečků patří tato část k nejstarším kolekcím ve sbírkách fonotéky, zároveň se i jedná o jednu z nejrozsáhlejších sbírek šelakových desek na území České republiky.

Dle dochované evidenční pomůcky muzea - inventární knihy s označením ME (pro standardní šelakové desky o průměru $30 \mathrm{~cm}$ ), byly príijaty první zvukové dokumenty do sbírek muzea v roce 1965. Nosiče byly depozitně ukládány do objektu na Bertramce, a podle inventární knihy zde v roce 1970 bylo uloženo již 7090 desek. Tento enormní nárůst počtu nosičů od roku 1965, kdy je datován první prŕrůstek, byl pravděpodobně zapř́íciněn dobovými historickými souvislostmi. Svou roli zde sehrála jistě generační obměna tehdejší společnosti. Generace lidí, kteři jádro svého produktivního věku zažili ve dvacátých a trricátých letech (tedy v éře, kdy se standardní gramofonová deska stala masovou záležitostî) postupně umírá. Šelakové desky se tak ve št’astněǰsím prŕípadě v té době ocitají jako "nechtěný dar" v muzeích, v horším pak degradují na odstrčených úložních místech, jako jsou půdy a sklepy, a to mnohdy až dodnes, či bohužel končí nenávratně na smetištích a skládkách. Souvisejícím a možná i důležitějším faktorem byl nástup vinylových desek na československý spotřebitelský trh, jimž nemohly šelakové desky prakticky konkurovat. V porovnání se standardní šelakovou deskou je vinyl lehčí, pružněǰší, odolněǰší a je na něj možné zaznamenat mnohem delší zvukovou stopu. Zatímco šelaková deska byla mnohdy poněkud ironicky považována za ekvivalent "porcelánového talíre"e- materiál je obzvláště křehký a př̀i sebemenším nárazu snadno praská. Rozsah inventárních čísel této řady je $\mathrm{v}$ evidenčních pomůckách zachycen $\mathrm{v}$ současnosti takto: $\mathrm{v}$ inventáŕi řady ME 1-7422, dále $\mathrm{v}$ katalogových lístcích i na katalogových kartách, a to ve fragmentárním rozsahu pro nosiče ME 1-706 a ME 7737-7855. To je z celkového počtu cca 28103 nedostačující a celkově neuspokojivý počet. I když je tedy fyzická evidence vybrané sbírky s označením ME vedena jak v inventární knize, tak na katalogizačních kartách, ani jedna z pomůcek však prozatím netvoři kontinuální celek.

Tento stav je problematický hned ve čtyřech rovinách:

1) Z hlediska evidence máme zaznamenaný pouze zlomek z celé sbírky. To způsobuje, že neexistuje evidenční pomůcka pro tuto inventární řadu, která by přinesla alespoň částečnou přehlednost o celku.

2) Části inventární řady, které dosud nikdy neprošly evidencí, není možné využít pro vystavování, a nelze je detailněji obsahově posoudit a zhodnotit. A navíc, pokud badatel či zájemce o studium zadá rešeršní dotaz, tento úsek sbírky mu zůstane skrytý

3) Mělo-li by dojít k výběrové digitalizaci, nelze se stoprocentní jistotou určit vybrané předměty, protože v neevidovaných částech inventární řady ME mohou být duplikáty již evidovaných nosičů, které jsou však v horším fyzickém stavu a kondici než ty ne-evidované.

4) Není znám fyzický stav sbírkových předmětů v neevidované části inventární řady ME, který zároveň může dlouhodobě negativně ovlivňovat celkové prostředí v depozitu. 
Proces digitalizace, jehož součástí je nezbytně také pořizování metadat, pomůže doplnit prakticky neexistující stav evidence ve sbírce standardních gramofonových desek z inventární řady ME, a to na dvou úrovních:

1) vytvořením nové evidenční tabulky v elektronické podobě, která obsahuje unifikované metadatové údaje, které svou strukturou a syntaxí umožňují adekvátně vyplnit př́slušná pole,

2) snímkováním digitálním fotoaparátem, které vytvárí podklady pro evidenční činnost (vytvơ̌ení evidenčního záznamu), a zároveň z dlouhodobého hlediska fyzicky ochraňuje sbírkový předmět.

\section{Nastavení parametrů elektronické evidence}

$\mathrm{Na}$ základě provedeného průzkumu stavu sbírky a zjištěných okolností o kvalitě dochované evidence bylo rozhodnuto o nutnosti digitalizace etiket nosičů a vytvoření nové elektronické evidenční tabulky. Zcela identicky bylo totiž vytvořeno záhlaví pro elektronickou evidenci.

Co se týče parametrů tabulky, celkové nastavení bylo vypracováno na základě poznatků z průzkumu sbírky, odborné znalosti kategorií obsažených na etiketě nosiče v kombinaci s převzatými a zavedenými termíny, a s ohledem na cílovou podobu požadované evidence, kdy jsme vycházeli také z Minimálního záznamu RDA/MARC 21 pro speciální monografické zdroje - zvukové dokumenty.

Kategorie tabulky byla nadefinována takto:

- prefix inventární řady označující sbírkové předměty Národního muzea - Českého muzea hudby sbírka gramofonových standardních desek z šelaku o průměru $30 \mathrm{~cm}-$ ME.

- Inventární číslo,

- vydavatel,

- objednací číslo,

- matriční ćíslo,

- skladatel nebo autor,

- název skladby,

- interpreti, orchestr, dirigent,

- druh nosiče,

- rozměr nosiče,

- poznámka,

- způsob nabytí,

- číslo prrírůstku a detaily provenience.

Je nutné a důležité podotknout, že uvedený způsob evidence není možné spojovat s katalogizací (1. Jmenný a věcný popis dokumentů, někdy chápaný úžeji pouze jako jmenný popis dokumentů, jindy obecněji jako tvorba katalogizačních záznamů pro různé druhy katalogů a jejich organizace. - 2. V době budování lístkových katalogů nauka o knihovních katalozích a o metodách jejich budování včetně jejich organizace. 
(Vodičková, 2013), tak jak jí praktikují katalogizátoři v knihovnách dle současných knihovnických pravidel popisu dokumentů RDA (Resource Description and Access - Popis zdrojů a př́stup k nim, mezinárodní katalogizační pravidla). Tento druh evidence nebyl cílem našeho průzkumu. Digitalizáty etiket zvukových nosičů mohou sloužit také v katalogizační praxi. České muzeum hudby katalogizuje svoje sbírky do softwaru od firmy KP-SYS - Verbis, který tvoři základ pro online katalog muzea. V budoucnu počítáme s tím, že evidenční tabulky budou upraveny a konvertovány i do tohoto systému.

Po nastavení a optimalizaci záhlaví tabulky bylo přikročeno $k$ další fázi, a to $\mathrm{k}$ fotografickému snímání etiket standardních gramofonových desek za účelem využití digitalizátů pro vytváření evidenčních záznamů ve zmíněné tabulce.

\section{Fotografování etiket jako stěžejní krok pro tvorbu evidenčního záznamu}

Etikety gramofonových desek byly nafoceny a následně pro potřeby evidence zprrístupněny on-line. Zpř́stupnění předcházela analýza, jak nejefektivněji sdílet dané digitální dokumenty takovou formou, která by pro osobu evidující gramofonové desky byla co nejdostupnější. Bylo přistoupeno k využití služby Google Fotky, která umožňuje bezplatně a bez limitu sdílet digitalizáty, respektive fotografie. Tato skutečnost rovněž eliminuje opakovanou manipulaci s gramofonovými deskami, a tedy nebezpečí jejich fyzického poškození. Zároveň se ukazuje, že popis (evidenci nebo základní katalogizaci) lze pořídit i jinou cestou, než ustanovují knihovnická pravidla, která vyžadují popis "de visu". Metoda popisu s pomocí digitalizovaných etiket je rychlejší a operativnější, byt' výslednou tabulku je pro potřeby standardní evidence či katalogizace nutno dále upravit, protože takové záznamy nemusí být knihovnicky dokonalé. $\mathrm{V}$ př́padě dosud neevidované sbírky je však mnohem podstatnější ji rychle a efektivně zmapovat tak, aby bylo možné posoudit její obsah mj. právě s ohledem na plánovanou digitalizaci. Tato evidence může rovnou sloužit i pro orientaci uživatelů (badatelů), což představuje velmi důležitý aspekt.

$\mathrm{V}$ rámci tohoto výzkumu nebylo naším cílem se zabývat nejlepším a nejvhodnějším postupem fotografického zachycení etiket pro účely digitalizace, následné archivace a zpř́ístupnění. Tomuto tématu se věnuje chystaná metodika v rámci jiného projektu: NAKI II - Nový fonograf: Zachyceni vérohodnébo obrazu etiket gramofonových desek. $Z$ důvodu technických omezení jsme byli donuceni nepřijmout doporučení Národní digitální knihovny v rámci pořizování digitalizátů ve formátu JPEG 2000 Joint Photographic Experts Group - metoda ztrátové komprese) v rozlišení 300 DPI (Dots per inch - údaj o počtu pixelů na délku jednoho palce $(2,54 \mathrm{~cm})$. Rovněž jsme nepřistoupili ani $\mathrm{k}$ aplikaci standardních muzejních postupů při dokumentaci sbírkových předmětů, nebot’ nebyl digitalizován celý předmět, ale pouze část s výpovědní hodnotou pro evidenci $-\mathrm{v}$ tomto př́padě etiketa se zrcátkem.

Součástí našeho průzkumu bylo také zjištění, jak se staví k problematice zachycení obrazu zvukových dokumentů - gramofonových desek. Městská knihovna v Praze v rámci projektu digitalizace zvukových nosičů používala na snímání gramofonových desek knižní skener značky BookEye 3A ve formátu JPEG v rozlišení 300 DPI (Šír, Vojîrová, 2013). Situace v zahraničí byla zmapována prostřednictvím osobních kontaktů (dotazů) a konferenčního mailu od Národního muzea (Filip Šír a Michal Studničný) na IASA 
(International Association of Sound and Audiovisual Archives - Mezinárodní asociaci zvukových archivů), ohledně problematiky fotografické digitalizace etiket gramofonových desek.

Odpovědi na tento dotaz vypovídají, že každá instituce $\mathrm{v}$ různých zemích prístupuje $\mathrm{k}$ fotografické digitalizaci zvukových dokumentů a gramofonových desek zvlášt', zcela individuálně a že neexistuje jednotné globální doporučení či metodika, podle kterých by instituce mohly zvukové dokumenty fotografické digitalizovat. Sunny Mathews z "Discs \& Machines" Gramophone Museum and Records Archive v Indii uvádí, že předpokladem pro úspěšnou obrazovou digitalizaci je nastavení osvětlení, tzn. nestínit údaje na zrcátku okolo etikety desky, nebo naopak nevytvářet odlesky od zrcátka. Zane Grosa, vedoucí audiovizuální studovny v Národní knihovně v lotyšské Rize zase uvádí, že k fotografické digitalizaci používají skener, kterým snímají pouze etikety desek, nikoliv celé desky. Archivační kopii pořizují v bezztrátovém formátu TIFF (Tagged Image File Format - jeden z mnoha formátů na ukládání obrazových souborů), v rozlišení 400 DPI. Uživatelská kopie pak ve formátu JPG, v rozlišení 200 DPI.

Pro účely průzkumu, tedy zjistit, co se ve sbírce nachází a vyhodnotit kulturně historickou hodnotu tohoto vzorku sbírky, bylo primárním cílem zachytit především čitelné údaje na etiketě a okolním zrcátku. Pro tento záměr se pořídily prrístroje: fotoaparát Canon Power Shot G1 X Mark II, osvětlovací techniku a difuzní stan. Digitalizace probíhala prímo v depozitáŕi, kde jsou gramofonové desky uložené. Následkem tohoto opatření se maximálně eliminoval fyzický pohyb sbírek. Byla tak pečlivě dodržena její bezpečnost a ochrana. Způsob digitalizace byl od počátku nastaven tak, aby pořízené snímky splňovaly podmínky unifikace a interoperability: tj. snadno sdílitelný a hojně používaný formát JPG, který zaručuje menší velikost souboru. Zvolili jsme cestu nestandardní, především účelově zaměřené digitalizace, která se soustředí primárně na zachycení a rozeznatelnost popisných údajů na etiketách, a to z obou stran desky. Poř̌zený snimek sice nemá

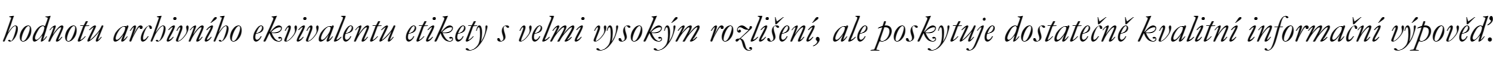

Důvody pro volbu těchto postupů v rámci celého procesu jsou následující:

1) Tímto způsobem lze poměrně snadno a neprýliš nákladně pořídit databázi digitálních obrázků etiket, které mohou posloužit jako pomůcka při orientaci ve sbírce.

2) Pokud k jednotlivým snímkům vznikne adekvátní evidence, bude možné se ve sbírce obsahově orientovat a provést výběrovou digitalizaci zvuku z desek. Existuje-li snímek etikety a jeho popis - at' už ve formě jednoduché evidence v elektronických pomůckách (tabulky aj.), nebo katalogového záznamu či lístku - můžeme na základě toho provést posouzení a výběr vhodných desek k digitalizaci zvuku. Kritéria výběru digitalizace gramofonových desek je řešena v rámci projektu NAKI II Nový Fonograf, DG18P02OVV032.

3) Evidence umožní eliminovat duplicitní sbírkové předměty (desky), systematicky tak bude možné vyřadit duplikáty. Vyřazování se musí ř́dit předem pevně stanovenými kritérii dané instituce.

4) Digitalizáty mohou být sdíleny v rámci sítě institucí Národního muzea a poskytnout informační zdroj např. pro výběr graficky zajímavých etiket, či potřebných gramofonových desek z hlediska obsahu, které mohou účelně sloužit k výstavní činnosti apod. 
Snímky etiket prošly vždy důkladným postprocesem formou kontroly kvality a kompletnosti snímku. Za pomocí softwaru Métamorphose pak byly snímky hromadně přejmenovány dle nastaveného klíče, který byl zaveden tak, aby název souboru vždy obsahoval inventární číslo řady s prefixem ME i stranu desky. Tzn. gramofonová deska s inventárním číslem ME 8204 měla v digitální podobě název souboru: ME_08204_01.jpg. Snímky pak byly po balíčcích o 500 digitalizátech dálkově zpř́istupněny pro evidenci a zároveň zálohovány na muzejním serveru.

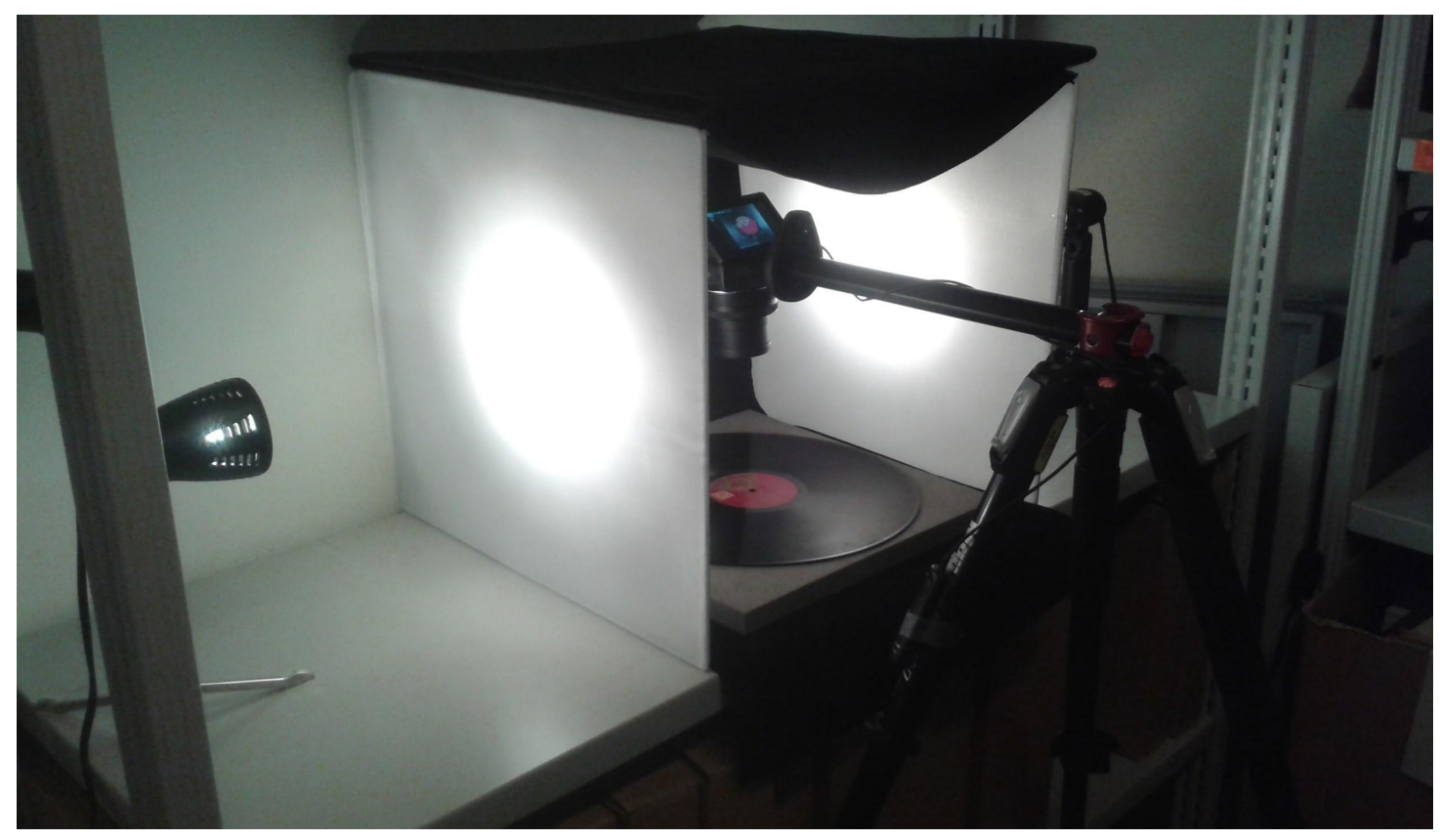

Obr. 1 Digitalizačni linka na snimáni etiket gramofonových desek v Ceském muzeu budby (foto: Michal Studničný)

\section{Závěr}

Předložený článek usiluje o prezentaci institucionálního kontextu, širší souvislosti, průběhu a výsledků průzkumu prvních deseti tisíc nosičů v inventární řadě ME ze sbírek fonotéky Národního muzea - Českého muzea hudby. Cílem předloženého textu je zejména představit možný postup/návod $\mathrm{k}$ řešení torzovitosti evidence zmíněné sbírky - v našem př́padě standardních gramofonových desek. Tímto řešením se ukázalo zavedení digitalizačního procesu fotografického snímání etiket standardních gramofonových desek, včetně jejich následné elektronické evidence.

Digitalizace vybrané sbírky zvukových nosičů se osvědčila hned v několika rovinách. V prvé řadě je to potenciál posloužit $\mathrm{v}$ pamět'ových institucích jako nástroj pro evidenci a katalogizaci, aniž by musel být samotný sbírkový předmět (gramofonová deska) fyzicky v rukou katalogizátora. Tento aspekt významně eliminuje riziko fyzického poškození. Elektronická evidence se oproti tomu může stát široce dostupnou a snadno prohledatelnou evidenční pomůckou (at’ už se jedná o katalog, databázi atd.) pro účely nejen odborných rešerší a specializovaných výzkumů, ale i pro potřeby badatelů z řad laické veřejnosti. Zároveň poskytuje za pomocí běžných funkcí jako filtrace, či nejvyšší výskyty (skladatelů, firem, které desky vydávaly aj.) a statistické přehledy možnost zkoumat tento segment sbírky ve zcela nových rozměrech a operativně. 
Př́kladem je zpracování statistik s výkladem historického kontextu z pera Gabriela Gössela. Text, v němž se spojuje jeho přehled o nových technologických možnostech evidence zvukových nosičů s hlubokými odbornými znalostmi tématu, je pŕ́lohou tohoto textu.

Co se týče budoucích výhledů, $\mathrm{v}$ dalších etapách zpracování této rozsáhlé sbírky fonotéky bude určitě třeba lépe promyslet aplikování knihovních nástrojů pro účely evidence a katalogizace dle současných knihovnických pravidel. Místo jednoduché evidenční tabulky bude zavedena předdefinovaná tabulka dle polí MARC 21 (Machine Readable Cataloguing - strojem čitelná katalogizace, význam zkratkového slova MARC se posléze ustálil jako označení skupiny formátů založených na mezinárodní normě ISO 2709 pro výměnu bibliografických informací a dalších souvisejících údajů ve strojem čitelné formě; viz též ČSN ISO 2709010157 Informace a dokumentace - Formát pro výměnu informacî) a vyplněna již s ohledem na pravidla RDA, aby mohla taková tabulka sloužit jako zdroj pro následnou migraci dat do katalogizačního systému. V tabulce totiž chybí nap̌r. sloupec pro místo a datum vydání, či předmětovou kategorii (žánr hudby). Užitý postup, tj. pořizování dat mimo prostředí knihovního systému však přináší několik výhod:

- pořizovat mohou i lidé bez velké katalogizační praxe - samozřejmě po zaškolení,

- v prípadě selhání online prostředí, ve kterém se knihovní katalog nachází, lze s tabulkou pracovat off-line a vzdáleně z domova,

- pro pořizovatele není třeba zřizovat vzdálené př́stupy do knihovního systému, což správci katalogu mnohdy vítají,

- pořizovatel se nemusí učit obsluhu knihovního systému, vyplňuje minimum údajů jednoduše do sloupečků tabulky a dosáhne tak mnohem rychleji vysokého počtu záznamů,

- knihovní katalog se nezanáší nesprávnými údaji (autoritní tvary jmen apod.),

- tabulka také slouží jako podklad pro inventarizaci sbírek.

Pochopitelně takto pořízené záznamy bude pro potřeby knihovního systému programátorsky upravit, což $\mathrm{v}$ př́padě kvalitního namapování a zadání požadavků na vygenerování potřebných údajů nebude problém.

\section{Dedikace}

Předložený článek vznikl za finanční podpory Ministerstva kultury v rámci institucionálního financování dlouhodobého koncepčního rozvoje výzkumné organizace Národní muzeum (DKRVO 2019-2023/24.II.a, 00023272). 


\section{Př́loha: výsledky evidence a statistiky}

V průběhu roku 2017 bylo nafoceno prvních 10000 desek z celých 28103 . V následujících letech 2018 a 2019 bylo přistoupeno ke zpracovávání dalších částí sbírky v rámci fonotéky ČMH. Zde bylo právě využito zkušeností z tohoto pilotního projektu, přičemž evidenční postup byl překonán a zefektivněn. Inovované postupy a jejich výsledky by měly být $\mathrm{v}$ budoucnu prezentovány $\mathrm{v}$ dalším odborném článku. Zároveň se podařilo tento první úsek zrevidovat. Evidenci, která byla vůbec poprvé pořízena v elektronické podobě za pomoci nástroje Google tabulky, provedl významný sběratel a znalec historie nejstarších zvukových dokumentů na našem území, Gabriel Gössel. Za pomocí obvyklých funkcí elektronické tabulky vytvořil statistiky nejčastěji se vyskytujících záznamů ve vybraných kategoriích: názvů firem, které desky vyráběly; a dále nejčastějších výskytů hudebních interpretů, skladatelů, orchestrů a dirigentů. Připojena je také statistika poškozených nosičů. Gabriel Gössel zároveň ke každé z př́slušných tabulek vytvořil průvodní historický exkurz.

\section{Firmy vydávající desky}

\begin{tabular}{|l|l|}
\hline firma & $\begin{array}{l}\text { počet sbírkových předmětů } \\
\text { z inventární řady ME } \\
\text { (gramofonové standardní desky } \\
\text { z šelaku o průměru } 30 \text { cm) }\end{array}$ \\
\hline Supraphon & $\mathbf{2 7 2 8}$ \\
\hline His Master's Voice (HMV) & $\mathbf{7 6 0}$ \\
\hline Electrola & $\mathbf{7 1 7}$ \\
\hline
\end{tabular}

Tab. 2 Výbèr nejvice se vyskeytujicich firem ve sbirce

1. Supraphon: není překvapující skutečností, že zdaleka nejvíce gramofonových desek ve sbírkách Českého muzea hudby pochází z této vlajkové etikety n. p. Gramofonové závody. De iure byl n. p. Gramofonové závody založen ministerstvem průmyslu 1. ledna 1946 jako důsledek zestátnění, resp. znárodnění veškerých gramofonových firem, které se na území ČSR účastnily před 9. V. 1945 na výrobě gramofonových desek. Československý gramofonový průmysl byl zestátněn vyhláškou č. 100 (tedy jedním z Benešových dekretů) ze dne 24. X. 1945. Znárodnění pak bylo realizováno vyhláškami č. 1218 a č. 1251 z roku 1946 a opravnými vyhláškami č. 1874 a č. 2040 z téhož roku. Monopol etikety Supraphon, jakožto etikety gramofonové desky trval až do roku 1968, nicméně výroba šelakových desek byla v ČSR ukončena již v roce 1962. Část produkce n. p. GZ byla v první polovině 50. let paralelně lisována i na vedlejší či účelové etikety Národní diskotéka a Armádní diskotéka, na něž byly umist'ovány především četné politicky i kulturně tendenční snímky 
poplatné tehdejšímu režimu. Na etiketě Supraphon vycházely také snímky některých význačných zahraničních umělců, hlavně z oblasti tzv. vážné hudby.

2. His Masters Voice: hlavní etiketa velké anglické společnosti Gramophone Co. Ltd. Založené již na přelomu 19. a 20. století a od roku 1932 součásti dodnes existujíćího koncernu Electric and Musical Industries (EMI). Relativně četný výskyt desek s touto etiketou ve sbírkách Českého muzea hudby je nepochybně dán i skutečností, že od roku 1911 byly desky této značky lisovány v továrně v Ústí nad Labem, distribuující až do roku 1938 své výrobky do všech nástupnických států bývalého Rakousko-Uherska. Pokud jde o český, resp. slovenský repertoár na gramofonových deskách této značky, za nejvýznamnějšš ediční počiny lze považovat souborná vydání Dvořákových Slovanských tancu a první kompletní nahrávku Prodané nevěsty na souboru 15 desek. Koncem 30. let byl název etikety dočasně změněn na počeštěnou podobu Hlas jeho pána.

3. Electrola: gramofonové desky s touto etiketou se od roku 1926 vyráběly v německém městě Nowawes u Postdamu. Tato gramofonová firma v anglickém majetku vznikla jako důsledek anglicko-německého vyrovnání po první světové válce a měla $\mathrm{k}$ dispozici veškeré matrice z produkce firmy The Gramophone Company. Pro export mimo Německo byly nahrávky této firmy lisované též na etiketu His Master's Voice. Z českých umělců byly na etiketu Electrola umist'ovány např́iklad snímky Emy Destinnové z matric anglické The Gramophone Company, nebo později cyklus Slovanské tance, natočený v roce 1935 v Londýně Českou filharmonií pod řízením Václava Talicha. V letech 1940-1941 pak byla v Praze pro tuto etiketu natočena a do německého katalogu této firmy zařazena řada snímků v podání předních českých umělců.

\section{Skladatelé}

\begin{tabular}{|l|l|}
\hline skladatel & $\begin{array}{l}\text { počet sbírkových předmětů } \\
\text { z inventární řady ME } \\
\text { (gramofonové standardní desky } \\
\text { z šelaku o průměru } 30 \mathrm{~cm} \text { ) }\end{array}$ \\
\hline Ludwig van Beethoven & 635 \\
\hline Antonín Dvořák & 620 \\
\hline Bedřich Smetana & 480 \\
\hline
\end{tabular}

Tab. 3 Výbèr nejvice se vyskytujicich skladatelì ve sbirce

Značnou část z celkového množství gramofonových desek v inventární řadě ME tvoří snímky na gramofonových deskách velkých německých firem, které v oblasti vážné hudby ovládaly nabídku desek na československém trhu hlavně ve 30. a 40. letech minulého století. Díla nejčastěji zastoupeného skladatele 
Ludwiga van Beethovena $(* 1770-\uparrow 1827)$ vycházela na mnoha deskových souborech koncertů, kdy nahrávka jeho jednoho opusu zpravidla představuje i několik desítek položek.

Poměrně nepřekvapivě jsou velice hojně zastoupení skladatelé Bedřich Smetana (*1824-†1884) a Antonín Dvořák (*1841-†1904). Jejich díla byla nahrávána již od počátku dvacátého století, někdy bohužel ne zcela kompetentními hudebními tělesy (nap̌r. sokolskými kapelami). Značné zastoupení nahrávek obou těchto skladatelů zaznamenáváme na gramofonových deskách značek Esta a Ultraphon v období okupace 1939_ 1945, po roce 1948 pak na gramofonových deskách značky Supraphon. Snaha o prezentování nahrávek děl obou těchto skladatelů coby vlasteneckých počinů bohužel poznamenala kvalitu některých snímků. Značnou negativní kritiku si vysloužil především projekt prvního kompletu „Prodané nevěsty“, natočené na patnáct desek značky His Master’s Voice (násobně zastoupených v inventární řadě muzea - ME) během roku 1933 a vydané o rok později u př́ležitosti akcí konaných k 50. výročí Smetanova úmrtí. Podobně značně rozdílnou zvukovou kvalitu měly četné nahrávky jednotlivých částí Dvořákova cyklu „Slovanské tance".

\section{Interpreti}

\begin{tabular}{|l|l|}
\hline interpreti & $\begin{array}{l}\text { počet sbírkových předmětů } \\
\text { z inventární řady ME } \\
\text { (gramofonové standardní desky } \\
\text { z šelaku o průměru } 30 \mathrm{~cm} \text { ) }\end{array}$ \\
\hline David Oistrach & 194 \\
\hline Josef Páleníček & 69 \\
\hline Georg Kulenkampff & 62 \\
\hline
\end{tabular}

Tab. 4 Výbèr nejvice se vyskytujicich interpretů ve sbirky

Dominance houslisty Davida Oistracha (*1908-†1974) je daná jak masovými dovozy sovětských desek po roce 1945 do Československa, tak rozsáhlým přjjímáním sovětských matric s nahrávkami a jejich lisováním na etiketu Supraphon. K nahrávání Oistrachova umění na domácí gramofonové desky byly využívány i jeho návštěvy Československa v průběhu 50. let 20. století.

Klavírista Josef Páleníček $(* 1914-† 1991)$ nahrál své první snímky pro firmu Ultraphon počátkem roku 1942 (kompozice Leoše Janáčka) a od roku 1944 nahrával i pro etiketu Esta (opět kompozice Leoše Janáčka a nově Fryderyka Chopina). Jeho četné nahrávky vycházely po roce 1947 na etiketě Supraphon.

Georg Kulenkampff $(* 1898-\dagger 1948)$ je nejčastěji zastoupen na gramofonových deskách německé etikety Telefunken. 


\section{Orchestry}

\begin{tabular}{|l|l|}
\hline orchestr & $\begin{array}{l}\text { počet sbírkových předmětů } \\
\text { z inventární řady ME } \\
\text { (gramofonové standardní desky } \\
\text { z šelaku o průměru } 30 \text { cm) }\end{array}$ \\
\hline $\begin{array}{l}\text { Česká filharmonie } \\
\text { Berlin }\end{array}$ & $\mathbf{1 0 8 9}$ \\
\hline $\begin{array}{l}\text { Symfonický orchestr hlavního } \\
\text { města Prahy FOK }\end{array}$ & $\mathbf{1 0 0}$ \\
\hline
\end{tabular}

Tab. 5 Výbèr nejvice se vyskeytujicich orchestru ve sbirce

\section{Dirigenti}

\begin{tabular}{|l|l|}
\hline dirigent & výskyt ve sbírce \\
\hline Václav Talich & 385 \\
\hline Václav Smetáček & 111 \\
\hline Rafael Kubelík & 92 \\
\hline
\end{tabular}

Tab. 6 Výbèr nejvice se vyskytujicich dirigentů ve sbirce

1. Česká filharmonie: Naprostá převaha snímků natočených Českou filharmonií nijak nepřekvapuje a je umocněná i četností zastoupení skladeb Antonína Dvořáka a Bedřicha Smetany v inventární řadě ME. Kromě snímků nahraných v Praze jsou zastoupeny i nahrávky České filharmonie realizované v Londýně (1937).

První snímky České filharmonie byly natočeny v Praze v roce 1929 pro etiketu His Master's Voice. Šlo o cyklus Má vlast, opakovaně v následujících letech vydávaný v reedicích. Kromě Václava Talicha Českou filharmonii dirigoval též profesor František Stupka. V Londýně natočenou Dvořákovu symfonii č. 5 - Novosvétskou (1937) dirigoval Georg Szell a ve stejné nahrávací frekvenci bylo natočeno ještě několik úryvků z cyklu Má vlast, kdy Českou filharmonii poprvé dirigoval Rafael Kubelík. Kubelík stál za dirigentským pultem i při natáčení vůbec posledních snímků České filharmonie pro anglický katalog 
nahrávek na značce HMV, jimiž byly předehry k Dvořákovým operám a Janáčkova Sinfonietta. Tyto snímky byly natočeny na podzim roku 1946 v prostorách Slovanského domu v Praze. (V řadě ME tyto snímky zastoupeny nejsou.)

V letech 1940-1941 natočila Česká Filharmonie s dirigentem Václavem Talichem rozsáhlou sérii snímků pro německou etiketu Electrola. Za zmínku v této souvislosti stojí, že v červnu roku 1941, jen pár dní před přepadením SSSR, natočila Česká filharmonie též kompletní 4. symfonii Petra Ilijiče Čajkovského. Tato nahrávka však již nebyla na gramofonové desky lisována.

V období nacistické okupace využívala domácí gramofonová firma Esta k nahrávání snímků vy̌ššiho populáru či operních předeher služeb České filharmonie. Na těchto snímcích byl soubor řízen několika předními českými dirigenty a na etiketách gramofonové desky byl uváděn pod označením Český symfonický orchestr.

2. Orchestr a sbor Staatsoper Berlin: Četnost zastoupení tělesa Orchestr a sbor Berlínské státní opery v inventární řadě ME je dána relativně hojným zastoupením německých gramofonových desek značek Polydor a Telefunken vydaných ve 40. letech 20. století. Nahrávky tohoto tělesa na etiketě Polydor navíc již od poloviny třicátých let v Československu distribuovala česká gramofonová firma Esta. Některé snímky z matric firmy Telefunken mimo jiné vycházely od roku 1945 v přelisech na etiketě Ultraphon a později až do padesátých let na etiketě Supraphon.

3. Symfonický orchestr hlavního města Prahy FOK: Zakladatelem dnešního Symfonického orchestru hl. m. Prahy FOK byl na podzim roku 1934 dirigent Rudolf Pekárek. Jeho jádro tvořili profesionální hudebníci, kteří v důsledku nástupu zvukového filmu počátkem 30. let i dopadů hospodářské krize ztratili zaměstnání. Repertoárový rozsah tělesa byl vymezen slovy Film-Opera-Koncert, jejichž zkratka se stala součástí názvu orchestru. Díky nahrávání hudby k četným českým filmům 30. let a vystupováním ve vysílání Československého rozhlasu vešel orchestr ve známost a byla zajištěna jeho ekonomická existence. To umožnilo postupný rozvoj koncertní činnosti, jejímž hlavním protagonistou byl od samého počátku dr. Václav Smetáček, který se v roce 1942 stal šéfdirigentem souboru.

Orchestr FOK nahrával gramofonové desky pro domácí gramofonové firmy Ultraphon a Esta, po roce 1947 též pro n. p. Gramofonové závody.

\section{Poškozené sbírkové předměty - gramofonové desky}

Během procesu snímání etiket byl zaznamenáván i fyzický stav sbírkových nosičů. Fyzický stav nosičů byl zaznamenáván již v dř́ivější době, a to do evidenčních pomůcek inventární řady ME. Tyto záznamy však nejsou kompletní a chybí zde např. absence sbírkových předmětů a druhy poškození jednotlivých nosičů. Pro tyto účely byl vytvořen předávací protokol, ve kterém byla vygenerována souvislá řada inventárních čísel kromě záznamu o fyzickém stavu sbírkového předmětu (tedy zvukového nosiče), zde figuruje i datum focení, fyzický stav před focením i po focení a podpisy osob, které přebíraly sbírkové předměty v den focení. Obdobně byl veden soupis fyzického stavu i v elektronické verzi. Z celých deseti tisíc gramofonových desek 
z inventární řady ME bylo během focení a inventury fyzického stavu zaznamenáno, že je 202 gramofonových desek poškozeno, nebo nebyly na místě, což představuje 2,02\% zkoumaného segmentu. Nejvíce se vyskytujícím jevem z oblasti poškození byly praskliny. Důvodem tohoto poškození mohlo být nešetrné zacházení s nosiči, či jiné faktory. V př́ípadě odlomených fragmentů platil již zavedený postup, kdy se odlomená část uložila do obálky mimo sbírku desek a propojila nadepsaným inventárním č́slem.

\begin{tabular}{|l|l|}
\hline druh poškození & $\begin{array}{l}\text { počet sbírkových předmětů } \\
\text { z inventární řady ME } \\
\text { (gramofonové standardní desky } \\
\text { z šelaku o průměru } 30 \text { cm) }\end{array}$ \\
\hline prasklé & $\mathbf{9 0}$ \\
\hline $\begin{array}{l}\text { desky s odlomenými a } \\
\text { zachovalými částmi }\end{array}$ & $\mathbf{2 8}$ \\
\hline $\begin{array}{l}\text { desky s odlomenými částmi, } \\
\text { které se nezachovaly }\end{array}$ & $\mathbf{6 9}$ \\
\hline nebylo na místě během focení & $\mathbf{2 3}$ \\
\hline zlomené & $\mathbf{5}$ \\
\hline nespecifikované poškození & $\mathbf{1 0}$ \\
\hline sbírkových předmětů & $\mathbf{2 0 2}$ \\
\hline
\end{tabular}

Tab. 7 Shrnutí poškozenyich sbirkových prédmètů ze sbirky 


\section{Zdroje}

BENEŠOVÁ, Ludmila a Jana ŠTOROVÁ (2012). Zvukové záznamy bibliografický popis podle RDA. In: Národni knibovna Českébo republiky [online]. Praha: Národní knihovna Čr. Dostupné z: https://www.nkp.cz/o-knihovne/odborne-cinnosti/zpracovani-fondu/katalogizacni-politika/zvukovedokumenty-rda

ČÍŽEK, Bohuslav (1999). Mureum české hudby, historie a sbirky. Praha: Národní muzeum, Průvodce (Národní muzeum). ISBN 80-703-6055-0.

GÖSSEL, Gabriel (2001). Fonogram: praktický pruivodce bistorií ₹áąnamu zৃuku. Praha: Radioservis, 229 s. ISBN 808621219X.

GÖSSEL, Gabriel (2006). Fonogram: výlety k počátkưm historie záżnamu zunku. Praha: Radioservis, 563 s. ISBN 8086212440 .

GÖSSEL, Gabriel a Filip ŠÍR (2016). Gramatika etiket gramofonových desek: pomůcka pro katalogizaci historických desek z let 1900-1946. Praha: Národní muzeum. ISBN 978-80-7036-517-5.

HOROVÁ, Iva a Lenka HRUBÁ (2018). K otázkám popisu zvukových dokumentů v pamět’ových institucích. In: Http://repozitar.tecblib.cz/ ?ln=cs [online]. Praha: Národní technická knihovna. Dostupné z: http://repozitar.techlib.cz/record/1324/files/idr-1324_1.pdf

MARC. Machine Readable Catalogue (1990-). In: KZK: Databáze žkratek pro knihovnictví a informační obory [online]. Praha: Národní knihovna ČR. Dostupné http:/ /aleph.nkp.cz/F/?func=direct\&doc_number=000010225\&local_base $=$ KZK

MIŘÁTSKÝ, Josef (1958). Gramofonová deska. Praha: Státní nakladatelství technické literatury. L 26-B2-3I/5323.

ŠEDA, Jaroslav (1957). Co je na etiketě gramofonové desky. Praha: Gramofonové závody. ISBN X-5715218.

ŠÍR, Filip a Kateřina VOJÍŘOVÁ (2014). Projekt Digitalizace dlouhohrajících desek v Městské knihovně v Praze. Čtenár mèsičník pro knibovníky [online]. Dostupné z: https://svkkl.cz/en/ctenar/clanek/1091

VISK 5 Národní program retrospektivní konverze katalogů knihoven v ČR - RETROKON (2014). VISK: Verégné informační slǔ̌by kniboven [online]. Praha: Národní knihovna ČR. Dostupné z: https://visk.nkp.cz/visk-5

VODIČKOVÁ, Hana. Katalogizace (2003-). In: KTD: Čská terminologická databáze knibovnictví a informační védy (TDKIV) [online]. Praha: Národní knihovna ČR. Dostupné z: http:/ /aleph.nkp.cz/F/?func=direct\&doc_number=000001272\&local_base=KTD 
ŽALMAN, Jiř́, Milada KERVITCEROVÁ a Pavel JIRÁSEK (2002). Př́ručka murejníkova. Praha: Asociace muzeí a galerií České republiky. ISBN 80-86611-00-0.

\section{Poznámka o autorech}

Gabriel Gössel (*17.11.1943)

- e-mail: goessel@volny.cz

- soukromý sběratel historických zvukových nosičů a přehrávačů a člen projektu NAKI II - Nový fonograf

Martin Mejzr $(* 19.8 .1988)$

- e-mail: martin.mejzr@novyfonograf.cz

- instituce: Národní muzeum - Oddělení digitalizace a člen projektu NAKI II - Nový fonograf

Michal Studničný $(* 25.7 .1989)$

- e-mail: michal_studnicny@nm.cz

- instituce: Národní muzeum - České muzeum hudby a člen projektu NAKI II - Nový fonograf

\section{Filip Š́r $(* 19.1 .1987)$}

- e-mail: filip_sir@nm.cz

- instituce: Národní muzeum - Oddělení digitalizace a hlavní řešitel projektu NAKI II - Nový fonograf

- ORCID iD: https://orcid.org/0000-0002-2428-8059 